\title{
Analyses of asiatic hybrids resistance at introduction in northern forest steppe of west Siberia
}

\author{
Oksana Vronskaya $^{1, *}$, and Natalia Mosiahina ${ }^{1}$ \\ ${ }^{1}$ Federal Research Center for Coal and Coal Chemistry, Siberian Branch of the Russian Academy of \\ Sciences, Kuzbass Botanical Garden, Russia
}

\begin{abstract}
The contents of main pigments of photosynthetic apparatus ( chlorophyll a, b and carotinoid) in the leaves of Asiatic hybrids varieties during different stage of vegetation was first determined In conditions of northern forest steppe. It was established that 19 varieties of Asiatic hybrids had maximum level of accumulation of chlorophyll pigments (a and b) during the budding period, 4 - during the flowering period, 2 - during the fructification period; the most important value $\mathrm{a} / \mathrm{b}$ was proper to 8 varieties in the budding period, 6 - in the fructification period and 11 in the flowering period, the maximum accumulation of carotinoind contained in the budding period that was expressed in the adaptive reaction of plants aimed to increase of photosynthetic apparatus resistance during the most dry season period. Analyses of photosynthetic pigment contents in the leaves of Asiatic hybrids varieties showed that the flowing changes in the contents of pigment complex may be considered as indicators of a mechanism of adaptation of lily varieties to the complex of climatic and natural conditions of northern forest steppe of West Siberia.
\end{abstract}

\section{Introduction}

The main task of botanical gardens activity is a search of new plants for its introduction in the culture. Lilium L. genus from Liliaceae Juss. family counts about 105 species and more then 5 thousand varieties. Asiatic hybrids come in the first group of International garden classification of lilies [1,2]. They are known as decorative plant which used to create new varieties of lilies. This culture is under study in many regions of Russia and abroad [3-8].

Exchange of varieties of Asiatic hybrids between the botanical gardens allows to wide the range of varieties of collections, and to renew genofond. In such a case it's important that the plants adapt well for the complex of natural and climatic conditions of an introduction region. Much value in study of the plants condition has a studying of photosynthetic apparatus flexibility $[9,10]$ its adaptation to the varied conditions of introduction. The parameters of accumulation of photosynthetic pigments (chlorophyll a, b, carotinoind) contained in the leaves of Asiatic hybrids during different phase of vegetation

*Corresponding author: oksana_vronski@mail.ru 
serve as the plants resistance indicators to the complex of natural and climatic conditions. And such parameter analysis gives a definite image on an adaptation of plants to the growth conditions. Firstly the contents of main pigments of photosynthetic apparatus (chlorophyll $\mathrm{a}, \mathrm{b}$ and carotinoind) contained in the leaves of Asiatic hybrids varieties in different periods of vegetation in the conditions of northern forest steppe of West Siberia was defined and its indicator value. Studies objective: to define the contents of main pigments of photosynthetic apparatus (chlorophyll a, b and carotinoid) contained in the leaves of Asiatic hybrids varieties during different phases of vegetation, to define the varieties resistant tot the complex of natural and climatic conditions on the northern forest steppe of West Siberia.

\section{Materials and methods}

Studies were spent in 2012-14 years on the territory of Kuzbass botanical garden (Kemerovo city) located in the northern part of forest steppe area of West Siberia. Climate proper to the region under research - is sharply continental. The average monthly air temperature is about $-0.9{ }^{\circ} \mathrm{C}$. The higher temperature in summer is about $+35+38{ }^{\circ} \mathrm{C}$, and the lower temperature in winter is $-57^{\circ} \mathrm{C}$. The first spring frosts begin in the period from August 26 till September 14 Average annual precipitation is about $450-500 \mathrm{~mm}$, snowcover height is from 47 up to $72 \mathrm{~cm}$. Introduction populations - 25 varieties of Asiatic hybrids: 'Aelia', 'Virenea', 'Vostochnaya skazka', 'Zhizel', 'Zvezdochka', 'Kamilla', 'Kozette', 'Lastochka', 'Malinka', 'Narodnaya', 'Odetta', 'Poliushko', 'Polymia', 'Retro', 'Rozovaya dymka', 'Riabinka', 'Fleita', 'Yulia', 'Azurra', 'Alaska', 'Gold Lode', 'Nove Cento', 'Pepper', 'For you', 'White twinkle'. Number of a,b chlorophyll and sum of carotinoind was defined by the spectrophotometric method using the guidance papers [11, 12]. An analysis was made on the scanning device SPEK SSP-705. Statistical processing of finding was made using the PAST 3 device. Average error $( \pm \mathrm{m})$ and coefficient of variation $(\mathrm{V})$ were calculated per each parameter (M).

\section{Results}

Normal chlorophyll $\mathrm{a}, \mathrm{b}$ and carotinoind ratio is: chlorophyll $\mathrm{a}-50 \%$, chlorophyll $\mathrm{b}-30 \%$, and carotinoind $-20 \%$ [13].

As L. pilosiusculum is a local species well adapted to the conditions of northern forest steppe of West Siberia, the figures of the pigments content in its photosynthetic apparatus were compared with the introduced varieties of Asiatic hybrids of out of region origin.

It was established that 19 varieties of Asiatic Hybrids had maximum accumulation of chlorophyll pigments ( $\mathrm{a}$ and $\mathrm{b}$ ) during the budding period, 4 - during the flowering period, and 2 - during the fructification period. The most contents of chlorophyll contained in the leaves of L. pilosiusculum (a, 1,178 $\pm 0,3 \mathrm{mg} / \mathrm{g}, \mathrm{b}, 0,489 \pm 0,03 \mathrm{mg} / \mathrm{g}$ ). By compare the figures of chlorophyll contents of local species with the introduced it was determined that the contents of chlorophyll in the leaves of 'Lastochka', 'Pepper', 'For you' is near to L. pilosiusculum ( $\mathrm{a}, 0,932-1,563 \mathrm{mg} / \mathrm{g}, \mathrm{b}, 0,318-0,494 \mathrm{mg} / \mathrm{g}$ ). The contents of chlorophyll in the leaves of 'Rozovaya dymka' (a, 0,501 mg/g, b, 0,203 mg/g) is in 2 times lower than the local species one. Intraspecific and intravarietal variability of chlorophyll contents is average ( $\mathrm{V}=0,1-9 \%)$.

Quantity of chlorophyll a increased in 2,5-3 times the contents of chlorophyll $b$ in all the phenophases of development during the lily vegetation period. The varieties coefficient of variation for the years of study amounted to $\mathrm{V}=0,01-8,37 \%$. The highest index $(\mathrm{V}=8,37$ 
\%) was proper to the variety 'Rozovaya dymka'. 'Aelita' variety showed a stable contents of chlorophyll a and $\mathrm{b} \mathrm{V}=0,01 \%$.

One on informative figures characterizing the photosynthetic apparatus work is a correlation of chlorophyll a to chlorophyll $b(a / b)$. Such correlation is caused by the «main» chlorophyll a activity. The higher activity increases more the photosynthetic rate. Normally such a figure correspond to $2,2-3,0 \mathrm{mg} / \mathrm{g}$ of green weight [14].

Following the studies it was determined that 8 varieties had the highest value $a / b$ in the budding period, 6 - in the fructification period and 11 in the flowering period. By compare the average figures $\mathrm{a} / \mathrm{b}$ it was established that the varieties 'Lastochka' had the figures $(3,281 \mathrm{mg} / \mathrm{g})$, and 'Polymia' $(3,020 \mathrm{mg} / \mathrm{g})$ which are higher than such the figures proper to the variety L. pilosiusculum $(2,319 \mathrm{mg} / \mathrm{g}$ og green weight). Quantity a/b of all the varieties under study was within the standard values certifying the normal photosynthetic rate. The highest coefficient of $\mathrm{a} / \mathrm{b}$ variation in the flowering period was proper to the variety 'Fleita' $\mathrm{V}=4,01 \%$, the lowest $\mathrm{V}=0,1 \%$ was proper to the variety 'Aelita'.

It's known that carotinoid is an important element of lily's pigment system. It was determined that the most part of the introduced varieties of Asiatic hybrids showed the maximum accumulation of carotinoid in the budding period, expressed in the adaptive reaction of the plants aimed to increase resistance of photosynthetic apparatus in more dry season period. Quantitative content of carotinoid in the leaves of L. pilosiusculum $(0,368$ $\mathrm{mg} / \mathrm{g})$ was significant equal to the varieties 'Lastochka' $(0,305 \mathrm{mg} / \mathrm{g})$ and 'Kozette' $(0,393$ $\mathrm{mg} / \mathrm{g}$ ) and higher in 1,7 times than contained in the leaves of 'Vostochnaya skazka' $(0,221 \mathrm{mg} / \mathrm{g})$.

Correlation $\mathrm{a}+\mathrm{b} /$ carotinoid is no less important in characteristic of photosynthetic apparatus work. This correlation is stable in the norm and is sensitive to any changes in different environment factors. As L. pilosiusculum as the introduced varieties showed a tendency to reduce the correlation $\mathrm{a}+\mathrm{b} /$ carotinoid near to fructification period that reveal reducing of light-harvesting function of pigment complex under unfavorable temperature conditions

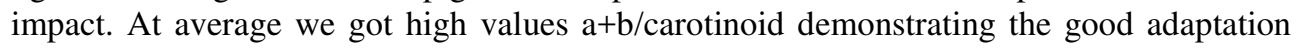
mechanism of Asiatic hybrids to the environment.

Correlation relationship reflects well the plants state as within the usual conditions as within the stresses. Studying intercorrelation of the photosynthetic pigments content we determined that all the varieties have the similar correlation dendrites and the Pleiades order. Total number of authentic correlation relationship ( $r \geq 0,601)$ is variable from 10 to 20. The high level of the parameters conjugation took place in 2013. The close intercorrelation between the studied signs is discernible: carotinoid, chlorophyll $a+b$, chlorophyll a/b; chlorophyll a and chlorophyll b (fig. 1).

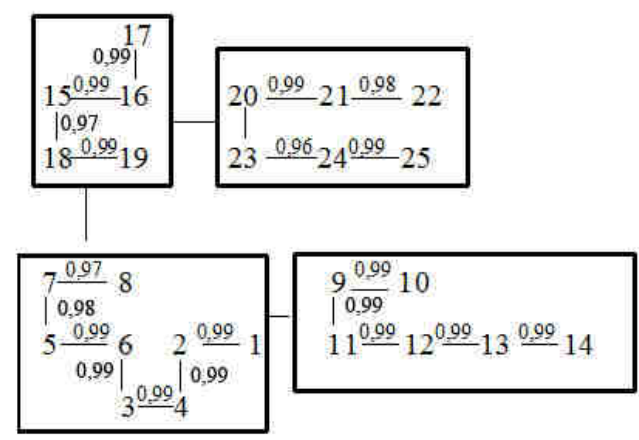

Fig.1. Correlation dendrite content of the main pigments of the photosynthetic apparatus (chlorophylls a and b, carotenoids) in the leaves of varieties of Asian hybrids. 1. 'Aelita', 2. 'Virineya', 
3. 'Vostochnaya skazka', 4. 'Zhizel', 5. 'Zvezdochka', 6. 'Kamilla', 7. 'Kozette', 8. 'Lastochka', 9. 'Malinka', 10. 'Narodnaya', 11. 'Odetta', 12. 'Poliushko', 13. 'Polymia', 14. 'Retro', 15. 'Rozovaya dymka', 16. 'Riabinka', 17. 'Fleita', 18. 'Yulia', 19. 'Azurra', 20. 'Alaska', 21. 'Gold Lode', 22. 'Nove Cento', 23. 'Pepper', 24. 'For you', 25. 'White twinkle'

On the dendrogram of varieties similarity over the pigment content built using the cluster analyses, the species family division is shown. Asiatic hybrids form a single cluster with a shoot height up to $75 \mathrm{~cm}$, another cluster includes the lilies with a culm length up to $75 \mathrm{~cm}$, and the other cluster includes the lilies with a culm length of $80 \mathrm{~cm}$ and more (fig. 2).

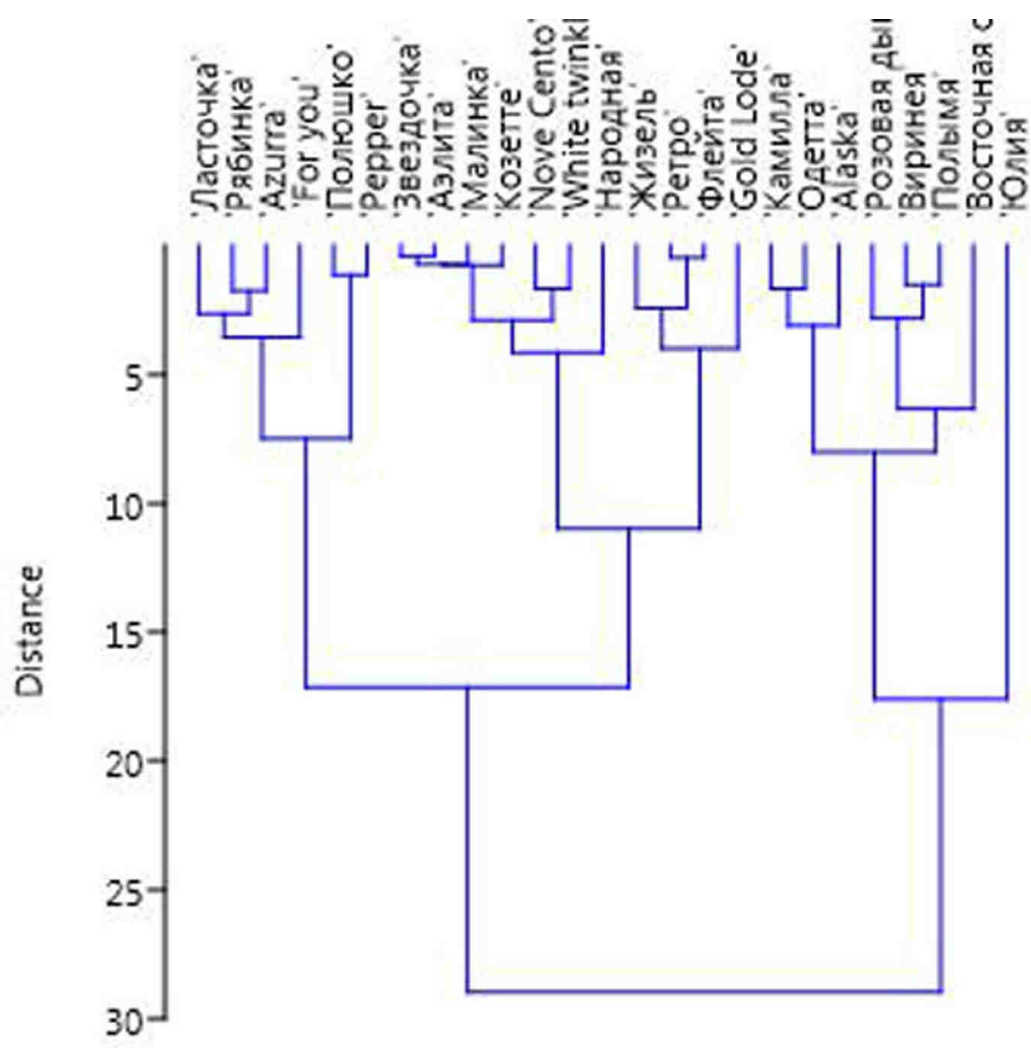

Fig. 2. Dendrogram of the similarity of varieties of Asian hybrids of lilies according to the content of photosynthetic pigments. 'Ласточка' ('Lastochka'), 'Рябинка' ('Riabinka'),'Azurra', 'For you', 'Полюшко' ('Poliushko'), 'Pepper', 'Звездочка' ('Zvezdochka'), 'Aelita', 'Малинка' ('Malinka'), 'Козетте' ('Kozette'),'Nove Cento', 'White twinkle', 'Народная' ('Narodnaya'), 'Жизель' ('Zhizel'), 'Ретро' ('Retro'), 'Флейта' ('Fleita'),'Gold Lode', 'Камилла' ('Kamilla'), 'Одетта' ('Odetta'), 'Alaska', 'Розовая дымка' ('Rozovaya dymka'), 'Виринея' ('Virineya'), 'Полымя' ('Рolymia'), 'Восточная сказка' ('Vostochnaya skazka'), 'Юлия' ('Yulia').

\section{Discussion}

Thus, the content of photosynthetic pigments contained in the leaves of Asiatic hybrids showed that the passing changes in the pigment complex structure may be considered as indicators of the mechanism of adaptation of lilies varieties to the complex of natural and climatic conditions on the northern forest steppe of West Siberia. The most varieties meet norms by every measure. It means that the formedness of photosynthetic apparatus of plants and its work ensured availability of a strong protective pigment system that allowed to the 
Asiatic hybrids varieties to develop well within the vegetation season. Analyses of contemporary foreign literary sources shows that the photosynthetic activity of the eastern hybrids of lilies increases in shade and reduces in water deficit $[15,16]$, i.e. is in complete accord with our opinion concerning protective function of photosynthetic apparatus. Based on the research findings we selected the varieties of Asiatic hybrids with well developed pigment system: lilies of subdivision I. Asiatic hybrids: 'Aelita', 'Virenea', 'Zvezdochka', 'Kamilla', 'Odetta', 'Poliushko', 'Retro', 'Yulia', 'Alaska', 'Gold Lode', 'Pepper', '4 you'.

\section{References}

1. The Internat. Lily Register, 377 (1982).

2. The Internat. Lily Register end checklist The Royal Horticultural Society, 948 (2007).

3. L.V. Zavadskaya. Modern lines of activity of botan. Gard. and botan. Collect., on the conservation of plant biodiversity, 241 - 244 (2005).

4. L.M. Kikot. Modern trends in the activities of botanical gardens and botanical collections for the conservation of plant biodiversity: Sat. materials, $99-100$ (2005).

5. K.B. Lim, M. Jaap van Tuyl. Lily. Lilium hybrids, 300 (2006).

6. S. Guven, S Okur, M Demirel, K. Coskuncelebi, S. Makbul1, O. Beyazoglu. Biol, 69/9, 1122-1133 (2014).

7. K. Lim., A. Younis, J. Taek Park, Y. Jung Hwang. Not Sci Biol. 6/2, 178-184 (2014).

8. O.O. Vronskaya. [Electronic resource]. Modern problems of science and education. 6 2015. http://www.science-education.ru/ru/article/view?id=23469.

9. M.M. Chaves, J. Flexas, C. Pinheiro. Ann. Bot, 103, 551-560 (2009).

10. K. Inamoto, K. Nagasuga, T. Yamazaki Yano, J. Hort. Sci. Biotech. 90, 259-266 (2015).

11. A.A. Shlik. Modern problems of photosynthesis 85, 108 (1973).

12. H.K. Lichtenhalter, A.R. Wellburn, Biochem. Soc. Rans. 11, 591-598 (1983).

13. E.V. Maksimova A.A. Kosicina O.N. Makurina, Vestnik Sam GU. 8, 146-152 (2007).

14. M.S. Titova, Vestnik OGUK. 12, 9-12 (2010).

15. Y.J. Zhang, Z.K. Xie, Y.J. Wang, P.X. Su, L.P. An, H.Gao, Rus. J. Plant Physiol. 58, 844 (2011).

16. Y.J. Zhang, Z.K. Xie, Y.J. Wang, P.X. Su, L.P. An, H.Gao, Rus. J. Plant Physiol. 62, 334-339 (2015). 